\title{
The Impact of Retail Store Global-Mindedness on Jordanian Consumers' Patronage Intention
}

\author{
Raed S. Algharabat ${ }^{1} \&$ Ahmad. M. A. Ahmad Zamil ${ }^{2}$ \\ ${ }^{1}$ Faculty of Business, Department of Marketing, The University of Jordan, Amman, Jordan \\ ${ }^{2}$ Faculty of Business, Department of Marketing, Middle East University, Amman, Jordan \\ Correspondence: Raed S. Algharabat, Faculty of Business, Department of Marketing, The University of Jordan, \\ Amman, 11942, Jordan。E-mail: r.gharabat@ju.edu.jo
}

Received: March 5, 2013

Accepted: April 3, 2013 Online Published: May 27, 2013

doi:10.5539/ijms.v5n4p30

URL: http://dx.doi.org/10.5539/ijms.v5n4p30

\begin{abstract}
This study aims to investigate the impact of Jordanian consumers' global-mindedness on retail store patronage. We measured consumer global-mindedness, second-order, via cultural openness and cultural adaptability. In order to test our proposed framework, we conducted a survey in three different Jordanian cities. Our results confirm that consumer global-mindedness is a multi-dimensional construct. Further, we found that Jordanian consumers' global-mindedness has positive impact on shopping enjoyment and cognition. In return shopping enjoyment and cognition have positive effects on store patronage.
\end{abstract}

Keywords: consumers' global-mindedness, cultural openness, cultural adaptability, shopping enjoyment, shopping cognition, retail patronage

\section{Introduction}

Globalization often leads to more openness among societies. Consumers all around the globe share similar tastes in lifestyles, music, clothing, and food. Therefore, global marketers offer a higher quality of life via introducing goods and services from different countries to satisfy consumers' needs and wants. Thus, global culture is emerging as a result of different factors (Alden, Steenkamp, and Batra 1999, 2006; Holt, Quelch, and Taylor 2004). For example, the spread of internet has contributed to seeing the world as one large market. The growth of world travel and global media have created interest in different global cultural products and brands which often associated certain meanings with certain places, people, and things (Caudle 1994). Previous researchers (Zhou, Teng, and Poon 2008; Steenkamp, Batra, and Alden 2003) on global consumers area examined the relationship between consumers openness to global culture and their use of global brands. As a result, stores and brands, through integrated media, are promoted worldwide and curry cultural meanings (Aaker, 1997; Aaker Maheswaran, Benet Garolera, 2001; Escalas and Bettman, 2005), thus, helping people to make sense of the world around them (Batey, 2008; Fournier, 1998). Consumers across the globe are using global brands, products and stores for a desire to be part of the global consumer community (Batra et al., 2000; Russell and Russell, 2006).

Previous research on consumer world-mindedness has focused on its impact on consumers' attitude and purchase behaviour toward product categories (Cleveland, Laroche, and Papadopoulos, 2009; Nijssen and Douglas 2008), brand positioning in advertisements (Alden, Steenkamp, and Batra, 1999), and attitude to advertising (Nijssen and Douglas, 2011). Yet, little is known about the interaction between consumer store world-mindedness and consumers' evaluations of the influence of other contingencies, such as store assortment and affective. Further, the relationship between store world-mindedness and store shopping motivations is not studied yet, to the best of the authors' knowledge. In order to bridge this gap, the current study aims to examine the impact of store world-mindedness on store shopping motivations which in return impact store patronage. Thus, this research aiming to answer the following questions:

How store world-mindedness impact shopping motivations (enjoyment and cognition).

How shopping enjoyment and cognition impact store patronizing.

This paper is organized as follows; we begin the paper with a review of relevant literature, which serves as a 
foundation for establishing our conceptual model and hypotheses. Then, we describe and justify our research method, leading to the results, implications and contributions to scholars and managers.

\section{Research Model and Hypotheses}

Figure 1 shows the research model and the hypothesized relationships among its variables which are all developed based on relevant literature. As shown in Figure 1, the model consists of six interrelated latent variables: cultural openness, cultural adoption, consumer world-mindedness, cognition, enjoyment, and store patronage.

\subsection{Consumer World-Mindedness}

Previous research on globalization (Medina and Duffy, 1998; Aaker and Joachimsthaler, 1999; Batra et al., 2000) emphasizes on the importance of global brands. For example, Medina and Duffy (1998, p. 230) define globalization as "the process of adopting country- and target-market-dictated product standards-tangible and/or intangible attributes from environments around the world to achieve a highly uniform product". Aaker and Joachimsthaler (1999) state that global brands include a similar look from one country to another. Townsend, Yeniyurt and Talay (2009) define global brands as "the face with which a firm portrays an image to a more diverse customer base". Batra et al. (2000) argue that global brands are perceived positively by general consumers and are perceived as status-enhancers. Global brands are often available across multiple nations; maintain their identity in the global markets (Van Gelder, 2003) and they provide consumers with prestigious and higher quality products (Steenkamp et al., 2003).

On the other hand, Hannerz (1990, p. 239) define a world-minded person as "someone who has a predisposition or willingness to engage with the "other" and thus is open to divergent cultural experiences". This definition often reflects the perception of cosmopolitanism and cultural adaptability (Thompson and Tambyah, 1999). Within the consumers context, applying this definition suggests key facets of cultural openness (related to an interest in and willingness to accept ideas and products from other cultures) which is related to the personality trait of openness to experience (Ferguson and Patterson 1998; McCrae and Costa 1997) and cultural adaptability (related to willingness to adapt to local habits and customs when in another country and to try products from other cultures at home). Furthermore, transposing world-minded definition to a consumer context suggests an interest in openness to and adoption of products, brands, ideas and stores from other cultures. World-minded consumers will also be more willing than other consumers to try and experiment with products from other cultures, both at home and when visiting these cultures, as a means to learn about and experience them.

To operationalize consumer world-mindedness, Nijssen and Douglas (2008) develop a two-dimensional (consumers' cultural openness and cultural adaptability) second-order scale. Furthermore, Nijssen and Douglas (2008, p. 88) relied on Hannerz's (1990) definition of a world-minded person which focuses on a person's ability to engage with different cultural experiences and posit that consumer world-mindedness "is related to the interest in, openness to, and adoption of products and ideas from other cultures or parts of the world and the acceptance of the norms and values of these cultures without nationalistic bias or prejudice". The above definition argues that world-minded consumers have the tendency to have more willing to try products from other cultures and they are more open to global brands and stores. Nijssen and Douglas (2008) find that consumer world-mindedness has a significant impact on store image. Westjohn, Singh and Magnusson (2012) find positive relationship between openness to experience (personality traits) and global identification. Thus in order to re-confirm Nijssen and Douglas' (2008) findings we hypothesis that:

H1: Consumer world-mindedness has a positive relationship with cultural openness.

H2: Consumer world-mindedness has a positive relationship with cultural adoption.

\subsection{Consumer World-Mindedness and Store Shopping Enjoyment and Cognition}

Beckmann et al. (2001) and Nijssen and Douglas (2008) describe world-minded consumers as people who are often respect diverse culture, eager to know more about their consumption habits, interested in international events, adore foreign travel and willing to try out products and brands from other cultures. As a result, Nijssen and Douglas (2008) assert that world-minded consumers have more positive attitudes toward foreign products and brands and they are more likely to purchase them. Cannon and Yaprak (2002) posit that world-minded consumers have positive attitudes toward a global culture and they realise it as a means of acquiring cultural capital which often enhance their status in their society.

Westjohn et al. (2012) find a positive relationship between global identification and attitude toward global consumer culture positioning. Nijssen and Douglas (2008) noted that retailers who responds to consumer world-mindedness often adapts a broader product assortment and establishing both specialized stores and stores 
with an international dimension. Nijssen and Douglas (2008) justify this because consumer world-mindedness is openness to ideas and products from other parts of the world. Further, previous research on this area (e.g., McCrae and Costa, 1997; Hannerz 1990) posit that consumers who are open to diverse experiences are more likely to appreciate authentic products and brands from other cultures and they are less likely to appreciate the traditions of their own culture.

According to Eroglu et al. $(2001,181)$ involvement refers to the degree of personal relevance, which is a function of the extent to which the online shopping activity is perceived to help achieve consumers' goals. Therefore, we posit that shoppers with a high global mindedness' involvement are likely to pursue central cognitive processes. Specifically, in order to form product attitudes and purchase decisions, we expect global mindedness shoppers to have high involvement, to be more concerned with the informational content regarding global stores because they view the shopping process as a means-end chain that links their activity with their goals. This view is consistent with the central vs. peripheral route information processing theory (Petty, Cacioppo, and Schumann 1983). Therefore, we expect a positive relationship between global mindedness and store shopping cognition to occur. Thus:

H3a: Consumer global-mindedness has a positive impact on store shopping cognition.

On the other hand, global mindedness shoppers often shop at different global retailers because they like to have fun more than information. This view has its roots in the literature (Holbrook and Hirschman, 1982; Babin, Darden, and Griffin, 1994; Baker, Levy, and Grewal 1992; Sherman, Mathur, and Smith, 1997). For example, results show positive association between store environment and consumers' affective state. Kim and Jin (2001) found a positive relationship between discount store attributes (e.g., neatness/spaciousness) and shopping excitement. Similarly, Yoo, Cannon and Yaprak (1998) found that consumers' emotional responses were induced by the store environment. Consumer shopping enjoyment culminates from pleasure and excitement triggered by the store environment. Swinyard (1993) posit that a pleasing store environment enhances a shopper's engagement in the shopping activity. Therefore, we expect a positive relationship between global mindedness and store shopping enjoyment. Thus:

H3b: Consumer global-mindedness has a positive impact on store shopping enjoyment.

\subsection{Shopping Enjoyment, Cognition and Patronage Intention towards the Store}

Previous research on the impact of shopping experience on store patronage improved its advantages. For example, Baker et al. (2002) find that shopping experience often contributes to enhance store patronage intentions. Baker et al. (1992) posit that shopping experience contributes to enhance affective reaction among shoppers. Baker, Parasuraman, Grewal \& Voss (20002) find a positive relationship between perceived merchandise value and store patronage intentions. A significant body of research (Bargh Chen, Burrows, 1996; Shah, 2003) asserts the importance of mental constructs and its impact on behavior. Therefore, we propose that environmental cues associated with global mindedness should affect consumers' evaluations of global stores, and, thus are effective in changing their behavioral intentions, patronizing global retailers (Zhang and Khare, 2009; Dogerlioglu-Demir and Tansuhaj, 2011). Previous scholarly literature shows a positive relationship between enjoyment derived from shopping environment and patronising the retailer. For example, Sinha and Banerjee (2004) assert a positive relationship between enjoyment and store patronage. Fiore et al. (2005) assert a positive relationship between enjoyment and patronizing. Further, the authors find a positive relationship between cognitive and patronizing. At the same context, Algharabat and Dennis (2010) find a positive relationship between hedonic, utilitarian values and behavioural intention toward the retailers. Therefore,

H4a: Store shopping cognition has a positive impact on store patronage.

H4b: Store shopping enjoyment has a positive impact on store patronage. 


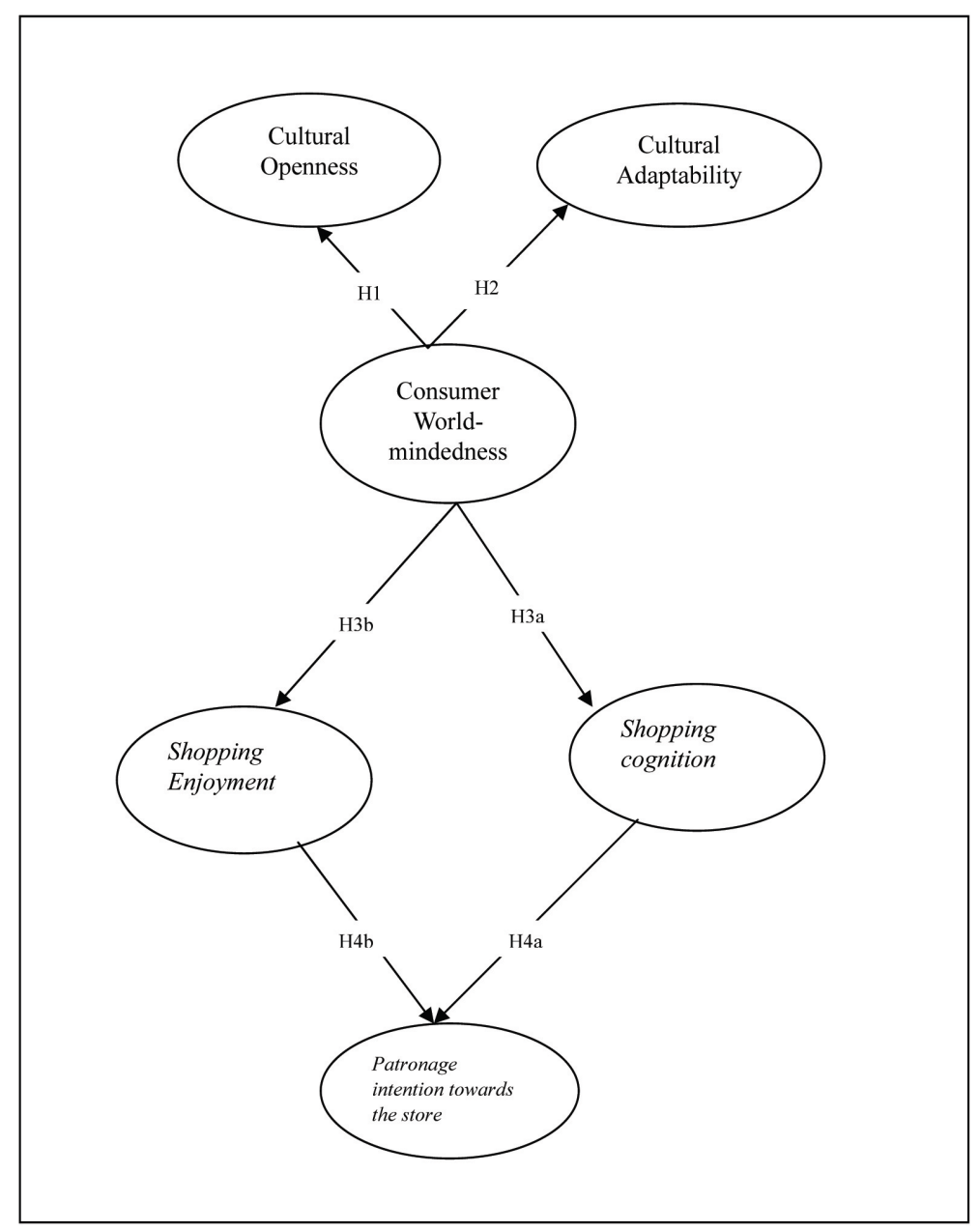

Figure 1. Proposed research model

\section{Method}

\subsection{Country Selection}

We conducted the study in Jordan using a survey instrument. Jordan is a country with a high level of foreign trade and stores, which makes it an appropriate context to examine the role of consumer world-mindedness. Many Jordanian travel outside the kingdom frequently and they are aware of activities and behaviour in different parts of the world. Furthermore, Jordan has high import/export flows. Furthermore, Jordanian community is best described as young one, more affected by the mass media and communication, and open to global products with more tendency to "Western iconness".

\subsection{Sample and Store Selection}

We have collected our data in three locations $(\mathrm{n}=300)$ : two major cities (Amman and Alzarqa) and a midsized regional city (Irbid). We choose three different locations because attitudes toward world-mindedness vary with the precise local environmental context (Nijssen and Douglas, 2008; Yoon, Cannon, and Yaprak 1996). We collected data from each location randomly based on selecting people at different locations in the city (e.g., malls, the public library, banks). Moreover, we approached consumers at these locations and we asked them to participate. Table 1 shows the demographic profile of the respondents. We chose global stores to examine the impact of consumer world-mindedness on store patronising. The chosen stores provide sections devoted to grocery and clothing products from other countries. 
Table 1. Demographic profile of the respondents

\begin{tabular}{|c|c|c|c|c|c|c|c|}
\hline Gender & Percentage & $\begin{array}{l}\text { Age in } \\
\text { Years }\end{array}$ & Percentage & Education & Percentage & $\begin{array}{l}\text { Income per } \\
\text { Month }\end{array}$ & Percentage \\
\hline Male & $50 \%$ & $18-24$ & 20.8 & $\begin{array}{l}\text { Less than } \\
\text { High school }\end{array}$ & 4.5 & $<\$ 1,000$ & 20.3 \\
\hline \multirow[t]{2}{*}{ Female } & $50 \%$ & $\begin{array}{l}25-34 \\
35-44 \\
45-54\end{array}$ & $\begin{array}{l}35.2 \\
17 \\
15.7\end{array}$ & $\begin{array}{l}\text { High school } \\
\text { Bachelor } \\
\text { Master } \\
\text { degree }\end{array}$ & $\begin{array}{l}12.5 \\
60.4 \\
17.6\end{array}$ & $\begin{array}{l}\$ 1,001-\$ 2,000 \\
\$ 2,001-\$ 3,000 \\
\$ 3,001-\$ 4,000\end{array}$ & $\begin{array}{l}35.5 \\
29.2 \\
5.2\end{array}$ \\
\hline & & $55+$ & 12.3 & $\mathrm{PhD}$ & 5 & $\begin{array}{l}\$ 4,001-\$ 5,000 \\
\$ 5,001-\$ 6,000 \\
>\$ 6,001\end{array}$ & $\begin{array}{l}3.6 \\
3.7 \\
2.5\end{array}$ \\
\hline
\end{tabular}

\subsection{Construct Operationalisation}

The participants were informed that this study pertained to consumer evaluations of a global retailer. The questionnaire contained seven-point Likert-type scales, anchored by $1=$ "strongly disagree" and $7=$ "strongly agree". The items and the supporting literature for the measurement scales are shown in Table 2.

To measure consumer world-mindedness, we focused on two dimensions; consumers' cultural openness construct (CCO), and consumer adaptability (CA). To measure CCO, we adopted a Four-item scale based on Cannon and Yaprak (1996), Hannerz (1990), Nijssen and Douglas' (2008) scale. To measure CA, we adopted a Four-item scale based on Hannerz (1990), Nijssen and Douglas' (2008). We used a modified version of Babian et al.'s (1994) scale to measure a three-item of cognition (COG). We used Kim and Jin's (2001) scale to measure enjoyment (ENJY). We measured store patronage intentions (PAT) with a scale developed by Dodds, Monroe and Grewal (1991).

Table 2. Research construct operationalisation

\begin{tabular}{|c|c|}
\hline consumer world-mindedness: consumers' cultural openness & Author (s) \\
\hline $\begin{array}{l}\text { CCO1: Even when consuming a particular foreign product does not fit the norms } \\
\text { and values of my own culture, I still try it. } \\
\text { CCO2: Even if I do not know how well a specific foreign brand will perform } \\
\text { beforehand, I try it } \\
\text { CCO3: When grasshopper is promoted as a delicacy in a Mexican restaurant in } \\
\text { the Netherlands, I like to try it. } \\
\text { CCO4: When a foreign friend recommends a product from his/her own culture } \\
\text { that is unknown to me, I am prepared to try it without any prejudice. }\end{array}$ & $\begin{array}{l}\text { Cannon, and Yaprak's } \\
(1996), \text { Hannerz }(1990), \\
\text { Nijssen and Douglas (2008) }\end{array}$ \\
\hline $\begin{array}{l}\text { consumer world-mindedness: consumer adaptability } \\
\text { CA1: If I move to the U.S. and I have to buy a car, then it is very likely that I } \\
\text { would switch to an American brand } \\
\text { CA2: Even though I (for example) would like French wine very much, I like to } \\
\text { drink wines from other traditional wine countries like Spain and Italy as well } \\
\text { CA3: Although I (may) have a favorite drink, when and for the time that I visit } \\
\text { another country I will drink the local alternative. } \\
\text { CA4: Although I prefer a certain type of food, when and for the time that I am } \\
\text { abroad I adopt the local cuisine }\end{array}$ & $\begin{array}{l}\text { Hannerz's (1990), Nijssen } \\
\text { and Douglas (2008) }\end{array}$ \\
\hline $\begin{array}{l}\text { Cognition: (COG1-COG3) while shopping at my store } \\
\text { COG1: I just accomplish what I want to. } \\
\text { COG2: I find just the items I look for. } \\
\text { COG3: I accomplished just what I wanted to on this shopping trip. }\end{array}$ & Babin et al. (1994) \\
\hline $\begin{array}{l}\text { Enjoyment (ENJY1-ENJY3) shopping at this store is } \\
\text { ENJY1: Exciting } \\
\text { ENJY2: Interesting } \\
\text { ENJY 3: Pleasant }\end{array}$ & Kim and Jin (2001) \\
\hline $\begin{array}{l}\text { Store Patronage (PAT1- PAT3) } \\
\text { PAT1: I would be willing to recommend this store. } \\
\text { PAT2: I would be willing to purchase through this store } \\
\text { PAT 3: In the future I would shop at this store }\end{array}$ & $\begin{array}{l}\text { Dodds, Monroe, and Grewal } \\
\text { (1991) }\end{array}$ \\
\hline
\end{tabular}




\section{Results}

We examined all scale items to reflect the hypothesised direction. We used a combination of Statistical Package for Social Sciences (SPSS 17), and Analysis of Moment Structure (AMOS 17). Further, we examined the univariate, skewness and kurtosis of the variables and found them to be within acceptable levels. We used a SEM using (AMOS) to determine the goodness-of-fit of indexes of the proposed model and to test the proposed hypotheses in our framework. Tabachnick and Fidell (2007, p. 676), posit that SEM is a "collection of statistical techniques that allow a set of relationships between one or more independent variables, either continuous or discrete, and one or more dependent variables, either continuous or discrete, to be examined". We employed SEM after the following reasons (Hair et al., 2006; Tabachnick and Fidell, 2007); (i) the simultaneous ability of the SEM to test several dependent relationships between observable indicators and the latent variable (the measurement model), and to test the relationships among latent variables (the structural model) by calculating multiple regression equations are greater than other statistical packages which examine only one single relationship in a time. (ii) SEM ability to calculate unidimensionality, reliability and validity of each construct individually. (iii) SEM ability to test the confirmatory factor analysis, rather than exploratory factor analysis. (iv) SEM ability to calculate measurement error and error variance parameters. (v) SEM ability to calculate the overall goodness-of-fit of the tested model.

\subsection{Measurement Models}

The analysis started by examining the structure and dimensionality of the study constructs using exploratory factor analysis (EFA) and reliability analysis. After examining the pattern matrix of the EFA, all items had loadings greater than 0.4 and communalities greater than 0.5 . We have found no crossed loaded in other factors.

We evaluated measurement properties by running AMOS 17.0. We treated the focal construct of consumer global-mindedness (CGM) as second-order construct, and its two dimensions (CCO and CA) are first-order factors measured through their respective indicators. The second-order CFA model fit was deemed to be acceptable on the basis of a battery of fit indexes $\left(\chi^{2}=85.792, \mathrm{df}=30\right.$; and $\left.\chi^{2} / \mathrm{df}=2.859\right)$ comparative fit index $[\mathrm{CFI}]=.901$; goodness-of-fit index $[\mathrm{GFI}]=.925$; Tucker-Lewis index $[\mathrm{TLI}]=.909$; incremental fit index [IFI $]$ $=.907$; root mean square error of approximation $[$ RMSEA] $=.0501$ ) (Table 3 ). The set of fit indexes reported is consistent with $\mathrm{Hu}$ and Bentler's (1999) recommendations. The path coefficients between the indicators and their respective first-order factors were significant at $\alpha=.05$ level. In addition, all the path coefficients between the second-order construct (consumer global-mindedness) and its two dimensions (CCO and AC) were significant at the $\alpha=.05$ level (Table 3). Furthermore, we conducted CFA for the four latent variables (CGM, COG, ENJY, and PAT). Results indicated that the fit indexes are consistent with Hu and Bentler's (1999) recommendations. $(\chi 2=293.639, \mathrm{df}=113$; and $\chi 2 / \mathrm{df}=2.599) \mathrm{CFI}=.924 ; \mathrm{GFI}=.919 ; \mathrm{TLI}=.908 ; \mathrm{IFI}=.925 ; \mathrm{RMSEA}=.052$.

Before estimating the path coefficients of the hypothesized structural model, we proceeded to fit a CFA on all the four latent factors: CGM, COG, ENJY, and PAT. Composite reliability is an indicator of the shared variance among the set of observed variables used as indicators of a latent construct (Fornell and Larcker 1981; Kandemir, Yaprak, and Cavusgil 2006). As Table 4 shows, construct reliabilities for all the three latent constructs ranged from, CGM (.97), COG (.82), ENJY (.81), and PAT (.79) all are acceptable (Hair et al. 1998). In addition, the coefficient alpha values were well above the threshold value of .7 that Nunnally (1978) recommends. The standardized factor loadings ranged from .83 to greater than .90 and were statistically significant at the $\alpha=.95$ level (Table 5). This provided the necessary evidence that all the constructs exhibited convergent validity.

We tested discriminant validity depending on the average variances extracted (AVE) values which should be within the cut-off point of 50\%. The discriminant validity is established by first, the absence of significant cross loadings that are not represented by the measurement model (i.e. congeneric measures). Second, we compared the shared variance among the constructs with AVE from each construct (Anderson and Gerbing 1988; Voss, Spangenberg and Grohmann 2003). The square roots of the average variance extracted by each construct exceed the correlation between them (Table 6), demonstrating discriminant validity.

\subsection{The Structural Model}

The structural model used to test the hypotheses consisted of all the three factors tested in the measurement model. The model fit measures indicated acceptable agreement with the covariance in the data. The results of the hypothesis testing support all postulated paths for H1-H6. We found that $\mathrm{CCO}(\beta=.70, \mathrm{p}<.001)$ and CA ( $\beta$ $=.86, \mathrm{p}<.001)$ have a positive impact on CGM. Furthermore, we found that CGM was positively associated with ENJY $(\beta=.46, \mathrm{p}<.001), \operatorname{COG}(\beta=.45, \mathrm{p}<.001)$, which in return impact PAT $(\beta=.42, \mathrm{p}<.001, \beta=.25, \mathrm{p}$ $<.001$ ). Coefficient of determination; for ENJY $=.20, \mathrm{COG}=.22$, and PAT $=.28$. However, this research finds that the direct impact of consumer global-mindedness on store patronage is non-significant, indicating that affect 
and cognition are fully mediating the relationship between consumer global-mindedness and store patronage.

Table 3. Results of the CFA: using a second-order conceptualization of GM

\begin{tabular}{|c|c|c|c|c|c|c|c|}
\hline Indicator & Direction & Construct & $\begin{array}{l}\text { Standardized } \\
\text { Loading }\end{array}$ & Estimate & SE & t-value & $\mathrm{P}$ \\
\hline $\mathrm{CCO} 1$ & $\leftarrow$ & $\mathrm{CCO}$ & .83 & .962 & .059 & 16.321 & $* * *$ \\
\hline $\mathrm{CCO} 2$ & $\leftarrow$ & $\mathrm{CCO}$ & .85 & 1.039 & .064 & 16.321 & $* * *$ \\
\hline $\mathrm{CCO} 3$ & $\leftarrow$ & $\mathrm{CCO}$ & .84 & 1.339 & .130 & 10.260 & $* * *$ \\
\hline $\mathrm{CCO} 4$ & $\leftarrow$ & $\mathrm{CCO}$ & .89 & .836 & .064 & 12.997 & $* * *$ \\
\hline CA1 & $\leftarrow$ & $\mathrm{CA}$ & .83 & 1.017 & .204 & 4.989 & $* * *$ \\
\hline CA2 & $\leftarrow$ & CA & .90 & .983 & .197 & 4.989 & $* * *$ \\
\hline CA3 & $\leftarrow$ & CA & .93 & .777 & .185 & 4.196 & $* * *$ \\
\hline CA4 & $\leftarrow$ & CA & .89 & .670 & .170 & 3.952 & $* * *$ \\
\hline $\mathrm{CCOa}$ & $\leftarrow$ & $\mathrm{GMb}$ & .96 & .872 & .051 & 17.139 & $* * *$ \\
\hline CAa & $\leftarrow$ & $\mathrm{GMb}$ & .99 & .459 & .052 & 8.829 & $* * *$ \\
\hline
\end{tabular}

a Second-order indicators.

$\mathrm{b}$ Second-order factor.

Notes: The respective indicators of CCO and CA are numbered serially (e.g., CCO 1, CCO 2, .., CA4).

Table 4. Measurement model: a scale properties of the four latent factors

\begin{tabular}{llll}
\hline Construct & Construct Reliability & Coefficient Alpha & AVE \\
\hline CGM & .97 & .96 & 0.95 \\
COG & .82 & .81 & 0.83 \\
ENOY & .81 & .80 & 0.78 \\
PAT & .79 & .80 & 0.74 \\
\hline
\end{tabular}

Table 5. Results of the CFA within the four latent factors

\begin{tabular}{|c|c|c|c|c|c|c|c|}
\hline Indicator & Direction & Construct & Estimate & $\begin{array}{l}\text { Standardised } \\
\text { Estimate }\end{array}$ & $\mathrm{SE}$ & t-value & $\bar{P}$ \\
\hline $\mathrm{CCO}$ & $\leftarrow$ & CGM & .607 & .50 & .066 & 9.183 & $* * *$ \\
\hline CA & $\leftarrow$ & CGM & .573 & .47 & .088 & 6.519 & $* * *$ \\
\hline COG & $\leftarrow$ & CGM & .181 & .86 & .031 & 5.838 & $* * *$ \\
\hline ENJY & $\leftarrow$ & CGM & .319 & .69 & .056 & 5.725 & $* * *$ \\
\hline PAT & $\leftarrow$ & ENJY & .417 & .42 & .066 & 6.278 & $* * *$ \\
\hline PAT & $\leftarrow$ & COG & .440 & .25 & .102 & 4.306 & $* * *$ \\
\hline $\mathrm{CCO} 1$ & $\leftarrow$ & $\mathrm{CCO}$ & 1.000 & .80 & & & \\
\hline $\mathrm{CCO} 2$ & $\leftarrow$ & $\mathrm{CCO}$ & 1.034 & .86 & .064 & 16.070 & $* * *$ \\
\hline $\mathrm{CCO} 3$ & $\leftarrow$ & $\mathrm{CCO}$ & 1.275 & .82 & .128 & 9.924 & $* * *$ \\
\hline $\mathrm{CCO} 4$ & $\leftarrow$ & $\mathrm{CCO}$ & .832 & .90 & .063 & 13.231 & $* * *$ \\
\hline CA1 & $\leftarrow$ & CA & 1.000 & .85 & & & \\
\hline CA2 & $\leftarrow$ & CA & 1.048 & .91 & . 167 & 6.283 & $* * *$ \\
\hline CA3 & $\leftarrow$ & CA & .866 & .92 & .152 & 5.714 & $* * *$ \\
\hline CA4 & $\leftarrow$ & CA & .513 & .86 & .118 & 4.359 & $* * *$ \\
\hline COG1 & $\leftarrow$ & $\mathrm{COG}$ & 1.000 & .65 & & & \\
\hline COG2 & $\leftarrow$ & COG & 1.858 & .94 & .185 & 10.040 & $* * *$ \\
\hline COG3 & $\leftarrow$ & $\mathrm{COG}$ & 1.459 & .93 & .142 & 10.269 & $* * *$ \\
\hline ENJY1 & $\leftarrow$ & ENJY & 1.000 & .84 & & & \\
\hline ENJY2 & $\leftarrow$ & ENJY & 1.050 & .93 & .105 & 10.015 & $* * *$ \\
\hline ENJY3 & $\leftarrow$ & ENJY & 1.025 & .87 & .104 & 9.841 & $* * *$ \\
\hline PAT1 & $\leftarrow$ & PAT & 1.000 & .82 & & & \\
\hline PAT2 & $\leftarrow$ & PAT & 1.147 & .85 & .058 & 19.633 & $* * *$ \\
\hline PAT3 & $\leftarrow$ & PAT & 1.059 & .90 & .059 & 17.900 & $* * *$ \\
\hline
\end{tabular}


Table 6. Internal consistency and discriminant validity of constructs

\begin{tabular}{|c|c|c|c|c|}
\hline \multirow{2}{*}{ Research Constructs } & \multicolumn{4}{|c|}{ Correlations } \\
\hline & 1 & 2 & & 4 \\
\hline 1. CGM & .97 & & & \\
\hline 2. $\mathrm{COG}$ & .25 & .91 & & \\
\hline 3. ENJY & .09 & .06 & .88 & \\
\hline 4. PAT & .24 & .15 & .23 & .86 \\
\hline
\end{tabular}

The figures under the diagonal are the Pearson (R) correlations between the variables. Diagonal elements are square roots of average variance extracted.

\section{Discussion}

This study aims to investigate the impact of consumer global-mindedness on Jordanian consumers' motivations to shop (affect and cognition) at global stores, which in return impact store patronage. Our findings, using a second-order, supported previous research (Nijssen and Douglas, 2008) which asserts that cultural openness and cultural adaptability are the main determinants of consumer global-mindedness. We found that consumer global-mindedness is a multi-dimensional construct.

The impact of consumer global-mindedness on store shopping enjoyment and store shopping cognition improved itself in our study. We found that Jordanian consumers prefer shopping at global stores since theses stores enhancing their entertainment experiences. This result comes in accordance with previous research which posits that enjoyment is one of the determinants of consumers' choice of retailers. The impact of consumer global mindedness on Jordanian consumers' cognition experiences also improved itself. We find that Jordanian consumers believe that global retailers provide them with more assortment, variety and high quality products. Further, Jordanian consumers believe that global retailers make their shopping experience easier and their task of buying faster. As we expected, enjoyment and cognition lead to store patronage. This result come in accordance with previous research (Dawar and Parker, 1994; Dodds, Monroe, and Grewal, 1991) which asserts that store patronage is a function of cognition processes (e.g., quality of the merchandise sold) and affect (e.g., promotions).

\subsection{Theoretical Implications}

We added, partially, to the literature the importance of focusing on consumer global-mindedness which impact through motivations store patronage. At the context of Jordan and many developing countries, global retailers should focus on shopping motivations. Our results show no direct impact of consumer global-mindedness on store patronage; rather it has an indirect impact on store patronage through shopping motivations. Previous research on this area (Nijssen and Douglas, 2008; Nijssen and Douglas, 2011) has not focus on the relationships between shopping motivations, created via consumer global-mindedness, and store patronage. Thus, this research has added an important aspect to the consumer global-mindedness area which related to shopping motivations.

\subsection{Managerial Implications}

The findings of our study have several implications for both global retailers and international marketing managers. We confirmed the results of previous research (Nijssen and Douglas, 2008) that cultural openness and adaptability are the main determinants of consumer world-mindedness. Furthermore, we find that enjoyment and cognition are significantly related to store patronizing. Therefore, the findings have consequences for not only retailer decisions about merchandise variety and assortment but also about promotional strategy.

International marketing managers should consider launching their brands through global stores when entering Jordan. In order to draw consumers' attentions, retailers should stock new foreign brands and demonstrate them in a separate section. Conducting promotional campaign inside the store, to feature products imported from a particular country or region using a special display to encourage product trial.

Consumers' intentions to store patronage can be influenced by the global store name in which that merchandise is sold above and beyond the value which consumers can perceive the global store offers. Thus, consumers often derive added value from the global store (e.g., I bought this product from a prestigious store; therefore it is a good value).

\section{Limitations}

We admit that our study suffers from several limitations. First, the study was conducted in a single country, 
Jordan, which was selected because consumers openness to ideas and products from foreign countries. In order to generalize our results, and to obtain a better understanding of the underlying relationships, further research is needed in countries with similar levels of environmental and international orientation (e.g., KSA, UAE, Qatar).

Second, our sample was young and well educated, further research is needed on older and less educated consumers to assess the generalizability of the results. Third, we did not test the impact of social-minded consumers on store patronizing. Further research could examine stores appealing to socially minded consumers. Fourth, we used store patronage, the dependent construct, in our study. However, the extent to which store image affects store choice remains open to question. Further research is needed to assess whether world-mindedness affect store loyalty.

\section{References}

Aaker, D. A., \& Joachimsthaler, E. (1999). The lure of global branding. Harvard Business Review, 77(6), 137-44.

Aaker, J. (1997). Dimensions of Brand Personality. Journal of Marketing Research, 34(3), 347-356. http://dx.doi.org/10.2139/ssrn.945432

Aaker, J. L., Maheswaran, D., Benet-Martı'nez, V., \& Garolera, J. (2001). Consumption symbols as carriers of culture: a study of Japanese and Spanish brand personality constructs. Journal of Personality and Social Psychology, 81(3), 492-508. http://dx.doi.org/10.1037/0022-3514.81.3.492

Alden, L., Steenkamp, J-B. E. M., \& Rajeev, B. (1999). Brand Positioning Through Advertising in Asia, North America and Europe: The Role of Global Consumer Culture. Journal of Marketing, 63(January), 75-87. http://dx.doi.org/10.2307/1252002

Alden, L., Steenkamp, J-B. E. M., \& Rajeev, B. (2006). Consumer Attitudes Toward Marketplace Globalization: Structure, Antecedents and Consequences. International Journal of Research in Marketing, 23(3), 227-39. http://dx.doi.org/10.1016/j.jiresmar.2006.01.010

Algharabat, R., \& Dennis, C. (2010). 3D Product Authenticity Model for Online Retail: An Invariance Analysis. International Journal of Business Science and Applied Management, 5(3), 14-30.

Anderson, J. C., \& Gerbing, D. W. (1988). Structural Equation Modeling in Practice: A Review and Recommended Two-Step Approach. Psychological Bulletin, 103(3), 411-423. http://dx.doi.org/10.1037/0033-2909.103.3.411

Armstrong, J. S., \& Overton, T. S. (1977). Estimating nonresponse bias in mail surveys. Journal of Marketing Research, 14(3), 396-402. http://dx.doi.org/102307/3150783

Babin, B., Darden, W., \& Griffin, M. (1994). Work and/or fun: measuring hedonic and utilitarian shopping value. Journal of Consumer Research, 20(4), 644-656. http://dx.doi.org/10.1086/209376

Baker, J., Levy, M., \& Grewal, D. (1992). An experimental approach to making retail store environmental decisions. Journal of Retailing, 68(4), 445-60.

Baker, J., Parasuraman, A., Grewal, D., \& Voss, G. B. (2002). The influence of multiple store environment cues on perceived merchandise value and patronage intentions. Journal of Marketing, 66(2), 120-41. http://dx.doi.org/10.1509/jmkg.66.2.120.18470

Bargh, J. A., Chen, M., \& Burrows, L. (1996). Automaticity of social behavior: Direct effects of trait construct and stereotype activation on action. Journal of Personality and Social Psychology, 71, 230-244. $\mathrm{http}: / / \mathrm{dx}$.doi.org/10.1037/0022-3514.71.2.230

Batey, M. (2008). Brand Meaning. New York, NY: Routledge.

Batra, R., Ramaswamy, V., Alden, D. L., Steenkamp, J. E. M., \& Ramachander, S. (2000). Effects of brand local and nonlocal origin on consumer attitudes in developing countries. Journal of Consumer Psychology, 9 , 83-95. http://dx.doi.org/10.1207/S15327663JCP0902_3

Beckmann, S., Gunter, B., Martina, B., Susan, P., Susanne, F., \& Nijssen, E. (2001). The Worldminded Consumer: An Emic Exploration. In Mary C. Gilly \& Joan Meyers-Levy (Eds.), Advances in Consumer Research (vol. 28, p. 138).

Cannon, H. M., \& Attilla, Y. (2002). Will the Real World Citizen Please Stand Up! The Many Faces of Cosmopolitan Consumer Behavior. Journal of International Marketing, 10(4), 30-52. http://dx.doi.org/10.1509/jimk.10.4.30.19550

Caudle, F. M. (1994). National Boundaries in Magazine Advertising: Perspectives on Verbal and Non-verbal 
Communication. In Basil D. Englis (Ed.), Global and Multinational Advertising (pp. 117-40). Hillsdale, NJ: Lawrence Erlbaum Associates.

Cleveland, M., Michel, L., \& Nicolas, P. (2009). Cosmopolitanism, Consumer Ethnocentrism, and Materialism: An Eight-Country Study of Antecedents and Outcomes. Journal of International Marketing, 17(1), 116-46. http://dx.doi.org/10.1509/jimk.17.1.116

Dawar, N., \& Philip, P. (1994). Marketing Universals: Consumers' Use of Brand Name, Price, Physical Appearance, and Retailer Reputation as Signals of Product Quality. Journal of Marketing, 58(April), 81-95.

Dodds. W, B., Keni, B, M., \& Dhruv, G. (1991). The Effects of Price, Brand, and Store Information on Buyers' Product Evaluations. Journal of Marketing Research, 28(August), 307-19. http://dx.doi.org/10.1016/S0022-4359(99)80099-2

Dogerlioglu, D. K., \& Tansuhaj, P. (2011). Global vs local brand perceptions among Thais and Turks. Asia Pacific Journal of Marketing and Logistics, 23(5), 667-683. http://dx.doi.org/10.1108/13555851111183084

Eroglu, S. A., Machleit, K. A., \& Davis, L. M. (2001). Atmospheric Qualities of Online Retailing: A Conceptual Model and Implication. Journal of Business Research, 54(2), 177-18. http://dx.doi.org/10.1016/S0148-2963(99)00087-9

Escalas, J. E., \& Bettman, J. R. (2005). Self construal, reference groups, and brand meaning. Journal of Consumer Research, 32(3), 378-89. http://dx.doi.org/10.1086/497549

Ferguson, E., \& Fiona, P. (1998). The Five Factor Mode of Personality: Openness a Distinct but Related $\begin{array}{lllll}\text { Construct. Personality and Individual } & \text { Differences, }\end{array}$ http://dx.doi.org/10.1016/0191-8869(95)00143-T

Fiore, A., Jin, H-J., \& Kim, J. (2005). For Fun and Profit: Hedonic Value from Image Interactivity and Responses towards an Online Store. Psychology \& Marketing, 22(8), 669-94. http://dx.doi.org/10.1002/mar.20079

Fornell, C., \& Larcker, D. F. (1981). Evaluating structural equation models with unobservable variables and measurement error. Journal of Marketing Research, 18(1), 39-50.

Fournier, S. (1998). Consumers and their brands: developing relationship theory in consumer research. Journal of Consumer Research, 24, 343-73. http://dx.doi.org/10.1086/209515

Griffitt, W. (1970). Environmental Effects on Interpertal Decisions. Journal of Retailing, 68(4), 445-60.

Hair, J. A. R., Tatham, R., \& Black, W. (1998). Multivariate Data Analysis. Upper Saddle River, NJ: Prentice-Hall.

Hannerz, U. (1990). Cosmopolitans and Locals in World Culture. In Michael Featherstone (Ed.), Theory, Culture and Society (pp. 237-51). London: Sage Publications.

Holbrook, M. B., \& Elizabeth, C. H. (1982). The experiential aspects of consumption: Consumer fantasies, feelings, and fun. Journal of Consumer Research, 2(September), 132-140. http://dx.doi.org/10.1086/208906

Holt, D. B., John, A. Q., \& Earl, L. T. (2004). How Global Brands Compete. Harvard Business Review, 82(9), 68-75.

Hu, L., \& Bentler, P. M. (1999). Cutoff criteria for fit indexes in covariance structure analysis: Conventional criteria versus new alternatives. Structural Equation Modeling, 6, 1-55. http://dx.doi.org/10.1080/10705519909540118

Kahn, B. E., \& Schmittlein, D. C. (1989). Shopping Trip Behavior: An Empirical Investigation. Marketing Letters, 1(1), 55-70. http://dx.doi.org/10.1007/BF00436149

Kandemir, D., Yaprak, A., \& Cavusgil, S. T. (2006). Alliance orientation: Conceptualization, measurement and impact on market performance. Journal of the Academy of Marketing Science, 34(3), 324-340. http://dx.doi.org/10.1177/0092070305285953

Kim, B., \& Park, K. (1997). Studying Patterns of Consumer's Grocery Shopping Trip. Journal of Retailing, 73(4), 501-517. http://dx.doi.org/10.1016/S0022-4359(97)90032-4

Kim, J. O., \& Jin, B. (2001). The mediating role of excitement in consumer satisfaction and repatronage intention of discount store shoppers in Korea. Journal of Shopping Center Research, 8(2), 117-13

Leszczyc, P. T. L., Sinha, A., \& Timmermansc, H. J. P. (2000). Consumer Store Choice Dynamics: An Analysis of the Competitive Market Structure for Grocery Stores. Journal of Retailing, 76(3), 323-345. 
http://dx.doi.org/10.1016/S0022-4359(00)00033-6

Levitt, T. (1983). The globalization of markets. Harvard Business Review, 61, May-June, 92-102.

McCrae, R. R., \& Costa, P. T. (1997). Personality Trait Structure as a Human Universal. American Psychologist, 52(5), 509-516. http://dx.doi.org/10.1037//0003-066X.52.5.509

Medina, J., \& Duffy, M. (1998). Standardization vs. globalization: A new perspective of brand strategies. Journal of Product and Brand Management, 7(3), 223-243. http://dx.doi.org/10.1108/10610429810222859

Nijssen, E. J., \& Douglas, S. P. (2008). Consumer World-Mindedness, Social-Mindedness and Store Image. Journal of International Marketing, 16(3), 84-107. http://dx.doi.org/10.1509/jimk.16.3.84

Nijssen, E. J., \& Douglas, S. P. (2011). Consumer Worldmindedness and Attitudes to Product Positioning in Advertising: An Examination of Global vs. Foreign vs. Local Positioning. Journal of International Marketing, 19(3), 113-133. http://dx.doi.org/10.1509/jimk.19.3.113

Nunnally, J. C. (1978) Psychometric theory. New York: McGraw-Hill.

Petty, R. E., Cacioppo, J. T., \& Schumann, D. W. (1983). Central and peripheral routes to advertising effectiveness: The moderating role of involvement. Journal of Consumer Research, 10, 134-148. http://dx.doi.org/10.1086/208954

Russell, D. W., \& Russell, C. A. (2006). Explicit and implicit catalysts of consumer resistance: the effects of animosity, cultural salience and country-of-origin on subsequent choice. International Journal of Research in Marketing, 23(3), 321-31. http://dx.doi.org/10.1016/j.ijresmar.2006.05.003

Shah, J. (2003). Automatic for the people: how representations of significant others implicitly affect goal pursuit. Journal of Personality and Social Psychology, 84(4), 661-81. http://dx.doi.org/10.1037/0022-3514.84.4.661

Sherman, E., Mathur, A., \& Smith, R. B. (1997). Store environment and consumer purchase behavior: Meditating role of consumer emotions. Psychology \& Marketing, 14(4), 361-378. http://dx.doi.org/10.1002/(SICI)1520-6793(199707)14:4<361::AID-MAR4>3.0.CO;2-7

Sinha, P., \& Banerjee, A. (2004). Store choice behaviour in an evolving market. International Journal of Retail \& Distribution Management, 32(10), 482-494. http://dx.doi.org/10.1108/09590550410558626

Steenkamp, J. E. M., Batra, R., \& Alden, D. L. (2003). How perceived brand globalness creates brand value. Journal of International Business Studies, 34(1), 53-65. http://dx.doi.org/10.2139/ssrn.339365

Swinyard, W. R. (1993). The Effects of Mood, Involvement, and Quality of Store Experience on Shopping Intentions. Journal of Consumer Research, 20, 271-280. http://dx.doi.org/10.1086/209348

Tabachnick, B. G., \& Fidell, L. S. (2007). Using Multivariate Statistics (5th ed.). Boston: Allyn and Bacon.

Thompson, C. J., \& Siok, K. T. (1999). Trying to Be Cosmopolitan. Journal of Consumer Research, 26(December), 214-41. http://dx.doi.org/10.1086/209560

Townsend, J. D., Yeniyurt, S., \& Talay, M. B. (2009). Getting to global: an evolutionary perspective of brand expansion in international markets. Journal of International Business Studies, 40(4), 539-58. http://dx.doi.org/10.1057/jibs.2008.87

Van Gelder, S. (2003). Global Brand Strategy: Unlocking Brand Potential across Countries, Cultures and Markets. Kogan Page, London.

Voss, K. E., Spangenberg, E. R., \& Grohmann, B. (2003). Measuring the hedonic and utilitarian dimensions of consumer attitude. Journal of Marketing Research, 40(3), 310-320. http://dx.doi.org/10.1007/BF00994132

Westjohn, S. A., Nitish, S., \& Peter, M. (2012). Responsiveness to Global and Local Consumer Culture Positioning: A Personality and Collective Identity Perspective. Journal of International Marketing, 20(1), 58-73. http://dx.doi.org/10.1509/jim.10.0154

Yoo, C., Park, J., \& MacInnis, D. J. (1998). Effects of store characteristics and in-store emotional experiences on store attitude. Journal of Business Research, 42(3), 253-63. http://dx.doi.org/10.1016/S0148-2963(97)00122-7

Yoon, S. J., Cannon, H. M., \& Yaprak, A. (1996). Evaluating the CYMYC Cosmopolitan Scale on Korean Consumers. Advances in International Marketing, 7, 211-232.

Zhang, Y., \& Adwait, K. (2008). Consumers' Local-Global Identity: Measurement. In Ann L. McGill \& Sharon Shavitt (Eds.), Advances in Consumer Research. Duluth, MN: Association for Consumer Research. 
Zhou, L., Lefa, T., \& Patrick, S. P. (2008). Susceptibility to Global Consumer Culture: A Three-Dimensional Scale. Psychology and Marketing, 25(4), 336-51. http://dx.doi.org/10.1002/mar.20212

\section{Copyrights}

Copyright for this article is retained by the author(s), with first publication rights granted to the journal.

This is an open-access article distributed under the terms and conditions of the Creative Commons Attribution license (http://creativecommons.org/licenses/by/3.0/). 